\title{
Motivators for Green Buildings: A Review
}

\author{
Mohamed A. S. Akreim \\ Cankaya University, Department of Interior Architecture, Balgat, 06530 Ankara, Turkey \\ Tel: 00-90-543-912-5037Ｅ-mail: almkeekrem@yahoo.com
}

\begin{abstract}
Assist. Prof. Dr. Ozge Suzer (Corresponding author)
Cankaya University, Department of Interior Architecture, Balgat, 06530 Ankara, Turkey

Tel: 00-90-532-731-1567Ｅ-mail: ozgesuzer@cankaya.edu.tr
\end{abstract}

Received: January 10, 2018 Accepted: February 2, 2018 Published: March 20, 2018

doi:10.5296/emsd.v7i2.12690ＵRL: https://doi.org/10.5296/emsd.v7i2.12690

\begin{abstract}
Motivators can be defined as specific catalysts that drive people to act in a certain way. These motivators are important for promoting green buildings and have a clear impact on decision-makers to adopt and implement the green building concept in architectural practice. This paper presents a comprehensive literature review to identify the important motivators for the adoption of green buildings among the stakeholders of the construction industry, the categorization and efficiency of green building motivators, and also the strategies for green building motivators.

By reviewing 32 relevant studies conducted in different countries from 2008 to 2017, a total of 26 factors were identified as the main motivators to promote green buildings. These green building motivators were categorized into environmental, economic, and social motivators. With regard to efficiency, it was found that all green building motivators, whether environmental, economic or social are important for promoting green buildings and to determine a priority among these categories was not possible. The strategies for the adoption of green building motivators were also found. It is notable that the government has the greatest role to motivate stakeholders to adopt and implement the green building concept.

The literature review of this study has a wide scope, covering most of the countries in the world, including developed and developing countries from the West to East. Hence, unlike most studies on the main issue of this paper that focus on a specific country or region, this in-depth research led to the development of a list of motivators for green buildings, derived from an extensive range of nations, which vary from environmental, economic, and social
\end{abstract}


aspects.

This paper is expected to provide valuable information for decision-makers in the construction industry, namely, governmental authorities, design teams, and owners of projects regarding what motivate people to help further promote green buildings. The findings may also be useful for researchers to pursue further analyses on similar topics.

Keywords: Green Building, Motivators, Incentives, Strategies, Decision-Makers

\section{Introduction}

Conventionally, the performance of building projects is measured based on cost, time, and quality. Recently, because of the climate change, global warming and lack of resources, the environmental issue has become a major concern in the construction industry (Dixon, McNamara, \& Newell, 2008). Sustainable projects take economic, environmental, and social factors into consideration. However, the environmental factor becomes more important among the three factors of sustainability (Shi, 2009).

As the buildings have significant impacts on the environment; it has become necessary to give more attention to the environmental performance in building design (Kerr, 2008). Buildings are accountable for about $40 \%$ of resource consumption, $30 \%$ of global energy consumption, and $40 \%$ of the global waste generation (N. Azizi, Fassman, \& Wilkinson, 2010). Moreover, buildings are responsible for more than $40 \%$ of global carbon dioxide emissions (Yudelson, 2013).

Based on the United States Green Building Council (USGBC), building 'green' is one of the major methods that are presented as a solution to reduce the global environmental damage (USGBC, 2012). Green buildings integrate design and construction activities to reduce the harmful impact on the environment and occupants, through five main categories, which are: sustainable sites, water efficiency, energy efficiency, interior environmental quality, and material resources (Yudelson, 2013). Green buildings aim to reduce the environmental footprint through reducing energy use by $30 \%$, water usage by $40 \%$, water sewerage by $70 \%$, and carbon dioxide emissions by 35\% (Varma, Chaurasia, Shukla, \& Ahmed, 2014).

Green buildings provide benefits not only from environmental, but also from economic and social aspects (Weeks, 2010). As to the economic perspective, they provide lower building life-cycle costs. As to the social perspective, they provide improved health and well-being, and comfort conditions for their occupants. Green approach gives a chance to the building industry to be a part of the sustainable development throughout the globe with its sustainable building solutions (Butera, 2010).

In light of the environmental, economic and social benefits of green buildings, motivators are needed to drive the stakeholders for the adoption of green design concepts in building construction (Odebiyi Sunday, Subramanian, \& Braimoh, 2010). Motivators can be defined as specific catalysts that are designed to drive people to act in a certain way. These motivators have a clear impact on decision-makers to adopt and implement the green building concept in practice (Qi, Shen, Zeng, \& Jorge, 2010). It is a social obligation for certification bodies to 
motivate project teams to consider the local conditions and the priority of environmental problems with respect to the location (Suzer, 2015). An overview of these motivators is fundamental in order to understand how green buildings can be more popular and successful (Darko, Zhang, \& Chan, 2017).

The term "motivators" refers to both the potential benefits of the green building system itself, and the actions or decisions taken by others that lead and motivate people to apply and adopt the green building concept. This paper provides a systematic review of the literature to identify; what the important motivators for the adoption of green buildings among construction stakeholders are; how literature categorized these motivators; what the efficiency of these green building motivators are; and what the strategies which are taken into account in literature as to green building motivators are, in order to provide valuable information for decision-makers in the construction industry, namely, governments, design teams, and owners of projects regarding what motivate people to help further promote green buildings.

\section{Research Methodology}

This study adopts literature review as its main method of data collection. As shown in Figure.1, this research follows a systematic review approach. At the beginning, an online search was conducted in well-known databases such as; Google Scholar, Scopus, and Research Gate, for the period of February 2017 until the end of April 2017, regarding 'the green building motivators' (Olubunmi, Xia, \& Skitmore, 2016), (Olubunmi et al., 2016), (Darko, Zhang, et al., 2017).

Through the search for the studies with regard to the keywords such as; 'green design motivators', 'green design incentives', and 'green design drivers', 350 publications were obtained. Then, by reading the abstracts and excluding the duplications, 173 studies remained and were downloaded into Endnote.

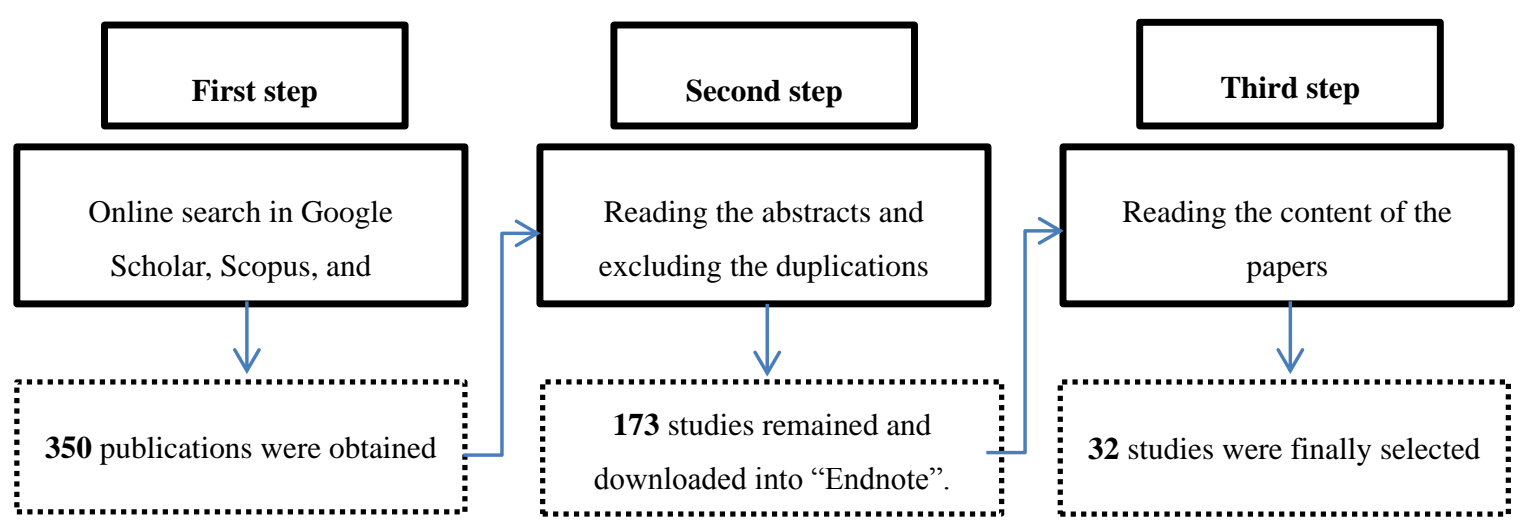

Figure 1. Research Process (produced by the author)

After the content review of the remained 173 studies, it was found that most of them just noted the existence and importance of motivators without mentioning what they are or giving details, and thus, did not give an adequate answer to the main research problem of defining 


\section{Macrothink}

the important motivators for the adoption of green buildings. Therefore, only the studies which actually clearly defined what the green building motivators were, were selected.

It was seen that, based on this criterion only 32 studies remained, which were journal articles, conference papers, theses, and reports, conducted during the period of 2008 - 2017, from different countries of the world including USA, New Zealand, Australia, Finland, Italy, Turkey, R-Korea, China, Hong Kong, Singapore, Malaysia, Sri Lanka, India, Nigeria, South Africa, Saudi Arabia, UAE, Oman, Palestine. Table 1. shows the distribution of the selected articles according to their country and publication type.

The sample size of 32 studies was considered acceptable, when compared to the past studies related to green building motivators. For example, Falkenbach, Lindholm, and Schleich, (2010) relied only on 20 papers to present a review on green building drivers, while, Darko, Zhang, et al., (2017) used 42 papers to present a review of empirical studies about drivers for green buildings. This relatively small sample size is attributed to the fact mentioned by Falkenbach et al., (2010), in their study as; "the number of published academic journal articles is altogether still low, and most of the published studies are either industry studies provided by various consultancy companies, or working papers".

Table 1. Distribution of the selected articles according to their country and publication type (produced by the author)

\begin{tabular}{|c|c|c|c|c|c|}
\hline \multirow[t]{2}{*}{ Countries } & \multicolumn{4}{|c|}{ Type of Publication } & \multirow[t]{2}{*}{ Quota } \\
\hline & Journal articles & $\begin{array}{l}\text { Conference } \\
\text { papers }\end{array}$ & Theses & Reports & \\
\hline USA & $\begin{array}{l}\text { (MacNaughton et al., } \\
\text { 2016) } \\
\text { (Darko, Chan, Ameyaw, } \\
\text { He, \& Olanipekun, 2017) }\end{array}$ & & & $\begin{array}{l}\text { (Construction, 2008), } \\
\text { (McGraw-Hill, 2013) } \\
\text { (Dodge, 2016) }\end{array}$ & 5 \\
\hline $\begin{array}{l}\text { New } \\
\text { Zealand }\end{array}$ & $\begin{array}{l}\text { (M. Azizi \& Sakina, } \\
\text { 2010) }\end{array}$ & & & & 1 \\
\hline Australia & $\begin{array}{l}\text { (Olanipekun, Xia, \& } \\
\text { Nguyen, 2017) } \\
\text { (Olubunmi et al., 2016) } \\
\text { (Olanipekun, 2016) }\end{array}$ & (Bond, 2010) & & & 4 \\
\hline Finland & $\begin{array}{l}\text { (Häkkinen \& Belloni, } \\
\text { 2011) }\end{array}$ & & & & 1 \\
\hline Italy & $\begin{array}{l}\text { (Aste, Caputo, Buzzetti, } \\
\text { \& Fattore, 2016) }\end{array}$ & & & & 1 \\
\hline Turkey & & & $\begin{array}{l}\text { (Gündoğan, } \\
\text { 2012) }\end{array}$ & & 1 \\
\hline R-Korea & $\begin{array}{l}\text { (Lee, Lee, Kim, \& Kim, } \\
\text { 2013) }\end{array}$ & & & & 1 \\
\hline China & $\begin{array}{l}\text { (Shen, Zhang, \& Zhang, } \\
\text { 2016) }\end{array}$ & & & & 2 \\
\hline
\end{tabular}




\begin{tabular}{|c|c|c|c|c|c|}
\hline & $\begin{array}{l}\text { (Darko, Zhang, et al., } \\
\text { 2017) }\end{array}$ & & & & \\
\hline $\begin{array}{l}\text { Hong } \\
\text { Kong }\end{array}$ & $\begin{array}{l}\text { (Chan, Qian, \& Lam, } \\
\text { 2009) } \\
\text { (Lam, Chan, Poon, Chau, } \\
\text { \& Chun, 2010) }\end{array}$ & & & & 2 \\
\hline Singapore & $(\mathrm{Ng}, 2013)$ & & & & 1 \\
\hline Malaysia & $\begin{array}{l}\text { (Azis, Sipan, \& Sapri, } \\
\text { 2013) } \\
\text { (Shazmin, Sipan, \& } \\
\text { Sapri, 2016) }\end{array}$ & $\begin{array}{l}\text { (Diyana } \& \\
\text { Abidin, 2013) } \\
\text { (Yang, } \quad \text { Chew, } \\
\text { Loo, \& Tan, } \\
\text { 2017) }\end{array}$ & & & 4 \\
\hline Sri Lanka & $\begin{array}{ll}\text { (Waidyasekara } & \& \\
\text { Fernando, 2013) } & \\
\end{array}$ & & & & 1 \\
\hline India & & & & (Deutsche, 2016) & 1 \\
\hline Nigeria & $\begin{array}{l}\text { (Dahiru, Dania, } \quad \& \\
\text { Adejoh, 2014) } \\
\text { (D. O. Nduka } \quad \& \\
\text { Sotunbo, 2014) }\end{array}$ & & & & 2 \\
\hline $\begin{array}{l}\text { South } \\
\text { Africa }\end{array}$ & (Windapo, 2014) & & & & 1 \\
\hline $\begin{array}{l}\text { Saudi } \\
\text { Arabia }\end{array}$ & (Usman \& Gidado, 2015) & & & & 1 \\
\hline UAE & (Azar \& Al Ansari, 2017) & & & & 1 \\
\hline Oman & $\begin{array}{l}\text { (Abidin \& Powmya, } \\
\text { 2014) }\end{array}$ & & & & 1 \\
\hline Palestine & (Rustom, 2014) & & & & 1 \\
\hline Total & 24 & 3 & 1 & 4 & 32 \\
\hline
\end{tabular}

\section{Findings}

\subsection{Identification of Green Building Motivators}

The term "motivators" is considered as any factor that encourages the decision-makers in the construction industry, including project owners, designers, architects, engineers and governmental authorities, to adopt and apply green building concepts in projects. These motivators may be caused by the characteristics and advantages of the green buildings, or may be through decisions or actions taken by others that may lead and motivate people to apply this system (Darko, Zhang, et al., 2017).

Identifying the motivators for the adoption of green buildings was the first objective of this study. To achieve this objective, the content of thirty-two selected studies was analyzed thoroughly in order to identify the important motivators, by avoiding the repetition of them. A list of twenty-six elements has been compiled as the possible motivators that would lead to the adoption of green design concept in construction projects (Table 2). Dodge Data and 
Analytics, in their report; 'World Green Building Trends 2016: Developing Markets Accelerate Global Green Growth', asked respondents to select the most important motivators from a list of 16 potential options that would increase their firm's involvement in green applications over time (Dodge, 2016).

As shown in Table 2, several motivators influencing green building implementation have been identified through a comprehensive review of past studies. Most of these studies have shown that the motivators related to the economic aspects such as reducing costs, saving money, and increasing profits are the most effective factors for the adoption of Green Building Concept, (Chan et al., 2009; Construction, 2008; Dahiru et al., 2014; Darko, Zhang, et al., 2017; Diyana \& Abidin, 2013; Dodge, 2016; Gündoğan, 2012; McGraw-Hill, 2013; D. Nduka \& Ogunsanmi, 2015; Ng, 2013; Shazmin et al., 2016). On the other hand, some studies have attributed the motivators related to the environmental and social aspects, such as; protection of the environment and ecosystem, control of climate change, waste reduction, and improving the quality of life as the most important factors (Abidin \& Powmya, 2014; Aste et al., 2016; Bond, 2010; Lee et al., 2013; MacNaughton et al., 2016; Rustom, 2014; Usman \& Gidado, 2015; Waidyasekara \& Fernando, 2013).

\subsection{Categorization of Green Building Motivators}

In order to comprehensively understand the green building motivators and their level of effectiveness in the implementation of green building development, it is essential to classify these motivators and to differentiate them (Darko, Zhang, et al., 2017). About half of the 32 selected studies just identified these motivators without any classification, while the remainder of these studies classified the green building motivators in different ways. Table 3 illustrates these classifications from the point of view of the authors of the 32 selected studies.

The motivators were classified by Turner Construction (2008), on a financial and non-financial basis, while, Diyana and Abidin (2013), and Abidin and Powmya (2014) classified them on a financial, knowledge, business, and ethical basis. On the other hand, Olubunmi et al. (2016), Olanipekun (2016), and Deutsche (2016), classified the motivators as external, and internal motivators.

However, the studies of Häkkinen and Belloni (2011), Handan Gundogan (2012), McGraw-Hill Construction (2013), Waidyasekara and Fernando (2013), Naim H. Rustom (2014), Usman and Gidado (2015), and Dodge Data and Analytics (2016) which make up the largest proportion of the 32 selected studies $(21.875 \%)$, classified green building motivators as environmental, economic, and social motivators, followed by $(9.375 \%)$ which classified them as external, and internal motivators. Based on this fact, the authors of this paper decided to classify the green building motivators under three main categories; which are: environmental, economic, and social motivators.

Table 3. The possible motivators derived from reviewing the selected studies, (produced by the author)

\begin{tabular}{l|l|r} 
No & Green Building & References
\end{tabular} 


\begin{tabular}{|c|c|c|}
\hline & Motivators & \\
\hline 1 & $\begin{array}{l}\text { Protection of the } \\
\text { environment and } \\
\text { ecosystem }\end{array}$ & $\begin{array}{l}\text { (Lam et al., 2010), (Bond, 2010), (Waidyasekara \& Fernando, 2013), (Lee et } \\
\text { al., 2013), (Ng, 2013), (Abidin \& Powmya, 2014), (Rustom, 2014), (D. } \\
\text { Nduka \& Ogunsanmi, 2015), (Darko, Zhang, et al., 2017), (Azar \& Al } \\
\text { Ansari, 2017), (Darko, Chan, et al., 2017) }\end{array}$ \\
\hline 2 & Control of climate change. & $\begin{array}{l}\text { (Bond, 2010), (Gündoğan, 2012), (Waidyasekara \& Fernando, 2013), (Lee et } \\
\text { al., 2013), (Rustom, 2014), (Aste et al., 2016) }\end{array}$ \\
\hline 3 & $\begin{array}{l}\text { Compatibility with } \\
\text { environmental regulations }\end{array}$ & $\begin{array}{l}\text { (McGraw-Hill, 2013), (Ng, 2013), (Dodge, 2016), (Shen et al., 2016), } \\
\text { (Darko, Zhang, et al., 2017) }\end{array}$ \\
\hline 4 & $\begin{array}{l}\text { Increasing indoor air } \\
\text { quality }\end{array}$ & $\begin{array}{l}\text { (Waidyasekara \& Fernando, 2013), (MacNaughton et al., 2016), (Darko, } \\
\text { Zhang, et al., 2017), (Darko, Chan, et al., 2017) }\end{array}$ \\
\hline 5 & $\begin{array}{l}\text { Recycling and waste } \\
\text { reduction }\end{array}$ & $\begin{array}{l}\text { (Lam et al., 2010), (Gündoğan, 2012), (Waidyasekara \& Fernando, 2013), } \\
\text { (D. Nduka \& Ogunsanmi, 2015), (Darko, Zhang, et al., 2017) }\end{array}$ \\
\hline 6 & $\begin{array}{l}\text { Improve reusable and } \\
\text { recycle building elements }\end{array}$ & (Lam et al., 2010) \\
\hline 7 & $\begin{array}{l}\text { Increasing building quality } \\
\text { and value }\end{array}$ & $\begin{array}{l}\text { (Chan et al., 2009), (Gündoğan, 2012), (McGraw-Hill, 2013), (Usman \& } \\
\text { Gidado, 2015), (Dodge, 2016), (Darko, Zhang, et al., 2017), (Yang et al., } \\
\text { 2017) }\end{array}$ \\
\hline 8 & $\begin{array}{l}\text { Providing lower operation, } \\
\text { maintenance, and repair } \\
\text { cost }\end{array}$ & $\begin{array}{l}\text { (Construction, 2008), (Chan et al., 2009), (Gündoğan, 2012), (McGraw-Hill, } \\
\text { 2013), (Diyana \& Abidin, 2013), (Ng, 2013), (Dahiru et al., 2014), (D. } \\
\text { Nduka \& Ogunsanmi, 2015), (Dodge, 2016), (Shazmin et al., 2016), (Darko, } \\
\text { Zhang, et al., 2017) }\end{array}$ \\
\hline 9 & $\begin{array}{l}\text { Providing lower building } \\
\text { life-cycle cost }\end{array}$ & $\begin{array}{l}\text { (Construction, 2008), (Lam et al., 2010), (Dahiru et al., 2014), (Shazmin et } \\
\text { al., 2016), (Darko, Zhang, et al., 2017), (Darko, Chan, et al., 2017) }\end{array}$ \\
\hline 10 & $\begin{array}{l}\text { Providing a good } \\
\text { opportunity for investment } \\
\text { returns }\end{array}$ & $\begin{array}{l}\text { (Construction, 2008), (Chan et al., 2009), (M. Azizi \& Sakina, 2010), } \\
\text { (Gündoğan, 2012), (Azis et al., 2013), (Ng, 2013), (Darko, Zhang, et al., } \\
\text { 2017), (Yang et al., 2017), (Darko, Chan, et al., 2017) }\end{array}$ \\
\hline 11 & $\begin{array}{l}\text { Increasing occupant } \\
\text { productivity }\end{array}$ & $\begin{array}{l}\text { (Construction, 2008), (Chan et al., 2009), (Ng, 2013), (Darko, Zhang, et al., } \\
\text { 2017), (Darko, Chan, et al., 2017) }\end{array}$ \\
\hline 12 & Increasing occupancy rate & (Construction, 2008), (Darko, Zhang, et al., 2017) \\
\hline 13 & $\begin{array}{l}\text { Increasing rental and sale } \\
\text { value }\end{array}$ & $\begin{array}{l}\text { (Construction, 2008), (Chan et al., 2009), (Azis et al., 2013), (Ng, 2013), } \\
\text { (Usman \& Gidado, 2015) }\end{array}$ \\
\hline 14 & $\begin{array}{l}\text { Providing lower annual } \\
\text { energy cost }\end{array}$ & $\begin{array}{l}\text { (Construction, 2008), (Lam et al., 2010), (Gündoğan, 2012), (Waidyasekara } \\
\text { \& Fernando, 2013), (Ng, 2013), (Windapo, 2014), (Rustom, 2014), (D. } \\
\text { Nduka \& Ogunsanmi, 2015), (Aste et al., 2016), (Shen et al., 2016), } \\
\text { (Shazmin et al., 2016), (Deutsche, 2016), (Darko, Zhang, et al., 2017), (Azar } \\
\text { \& Al Ansari, 2017) }\end{array}$ \\
\hline 15 & $\begin{array}{l}\text { Providing lower water and } \\
\text { wastewater cost }\end{array}$ & $\begin{array}{l}\text { (Bond, 2010), (Gündoğan, 2012), (Waidyasekara \& Fernando, 2013), } \\
\text { (Rustom, 2014), (D. Nduka \& Ogunsanmi, 2015), (Shen et al., 2016), } \\
\text { (Shazmin et al., 2016), (Darko, Zhang, et al., 2017), (Darko, Chan, et al., } \\
\text { 2017) }\end{array}$ \\
\hline 16 & $\begin{array}{l}\text { Giving a good reputation } \\
\text { for marketers }\end{array}$ & $\begin{array}{l}\text { (Chan et al., 2009), (McGraw-Hill, 2013), (Azis et al., 2013), (Ng, 2013), } \\
\text { (Darko, Chan, et al., 2017) }\end{array}$ \\
\hline
\end{tabular}




\begin{tabular}{|c|c|c|}
\hline 17 & $\begin{array}{l}\text { Availability of more } \\
\text { financing channels }\end{array}$ & (Azis et al., 2013), (Abidin \& Powmya, 2014) \\
\hline 18 & $\begin{array}{l}\text { Increase in demand of } \\
\text { clients/tenants }\end{array}$ & $\begin{array}{l}\text { (McGraw-Hill, 2013), (Usman \& Gidado, 2015), (Dodge, 2016), (Olubunmi } \\
\text { et al., 2016), (Deutsche, 2016), (Darko, Zhang, et al., 2017) }\end{array}$ \\
\hline 19 & $\begin{array}{l}\text { Product and material } \\
\text { innovation and/or } \\
\text { certification }\end{array}$ & (Dahiru et al., 2014), (Darko, Zhang, et al., 2017) \\
\hline 20 & $\begin{array}{l}\text { Providing improved } \\
\text { comfort, health, and } \\
\text { well-being of occupants }\end{array}$ & $\begin{array}{l}\text { (Construction, 2008), (Ng, 2013), (D. Nduka \& Ogunsanmi, 2015), (Usman } \\
\& \text { Gidado, 2015), (Dodge, 2016), (Olubunmi et al., 2016), (Darko, Zhang, et } \\
\text { al., 2017), (Darko, Chan, et al., 2017) }\end{array}$ \\
\hline 21 & $\begin{array}{l}\text { Improving the quality of } \\
\text { life for individuals }\end{array}$ & (Gündoğan, 2012), (Usman \& Gidado, 2015) \\
\hline 22 & $\begin{array}{l}\text { Satisfaction from doing the } \\
\text { right thing }\end{array}$ & $\begin{array}{l}\text { (McGraw-Hill, 2013), (Abidin \& Powmya, 2014), (Dahiru et al., 2014), } \\
\text { (Dodge, 2016) }\end{array}$ \\
\hline 23 & $\begin{array}{l}\text { Government regulations } \\
\text { and policies }\end{array}$ & $\begin{array}{l}\text { (M. Azizi \& Sakina, 2010), (Lee et al., 2013), (Abidin \& Powmya, 2014), } \\
\text { (Windapo, 2014), (Shen et al., 2016), (Deutsche, 2016), (Darko, Zhang, et } \\
\text { al., 2017) }\end{array}$ \\
\hline 24 & $\begin{array}{l}\text { Moral imperative or social } \\
\text { conscience }\end{array}$ & $\begin{array}{l}\text { (Bond, 2010), (Diyana \& Abidin, 2013), (Ng, 2013), (Darko, Zhang, et al., } \\
\text { 2017), (Azar \& Al Ansari, 2017), (Darko, Chan, et al., 2017) }\end{array}$ \\
\hline 25 & $\begin{array}{l}\text { Creating of better future } \\
\text { opportunities }\end{array}$ & (Ng, 2013), (Deutsche, 2016) \\
\hline 26 & Self-identity & $\begin{array}{l}\text { (M. Azizi \& Sakina, 2010), (Bond, 2010), (Abidin \& Powmya, 2014), } \\
\text { (Darko, Zhang, et al., 2017), (Darko, Chan, et al., 2017) }\end{array}$ \\
\hline
\end{tabular}

Table 4. Categorization approach taken by the authors of the 32 selected studies on green building motivators, (produced by the author)

\begin{tabular}{|c|c|c|c|}
\hline \multirow{2}{*}{$\begin{array}{c}\text { Categorization } \\
\text { Approach }\end{array}$} & \multicolumn{3}{|l|}{ Studies } \\
\hline & References & Number & $\%$ \\
\hline $\begin{array}{ll}\text { - } & \text { Financial } \\
\text { - } & \text { Non-financial }\end{array}$ & (Construction, 2008) & 1 & 3.125 \\
\hline $\begin{array}{ll}\text { - } & \text { External } \\
\text { - } & \text { Internal }\end{array}$ & (Olubunmi et al., 2016), (Olanipekun, 2016), (Deutsche, 2016) & 3 & 9.375 \\
\hline $\begin{array}{ll} & \text { Environmental } \\
\text { - } & \text { Economic } \\
\text { - } & \text { Social/Cultural } \\
\end{array}$ & $\begin{array}{l}\text { (Häkkinen \& Belloni, 2011), (Gündoğan, 2012), (McGraw-Hill, } \\
\text { 2013), (Waidyasekara \& Fernando, 2013), (Rustom, 2014), } \\
\text { (Usman \& Gidado, 2015), (Dodge, 2016) }\end{array}$ & 7 & 21.875 \\
\hline $\begin{array}{ll}\text { - } & \text { Stakeholder } \\
\text { - } & \text { Responsibility } \\
\text { - } & \text { Techniques } \\
\text { - } & \text { Feedback } \\
\end{array}$ & (Lam et al., 2010) & 1 & 3.125 \\
\hline $\begin{array}{ll}\text { - } & \text { Financial } \\
\text { - } & \text { Knowledge } \\
\text { - } & \text { Business } \\
\text { - } & \text { Ethical }\end{array}$ & (Diyana \& Abidin, 2013), (Abidin \& Powmya, 2014) & 2 & 6.25 \\
\hline
\end{tabular}




\begin{tabular}{|c|c|c|c|}
\hline $\begin{array}{ll}\text { - } & \text { Enhanced value } \\
\text { - } & \text { Costs/Savings } \\
\text { - } & \text { Sustainability } \\
\text { - Legislation }\end{array}$ & $(\mathrm{Ng}, 2013)$ & 1 & 3.125 \\
\hline $\begin{array}{l}\text { - } \text { Pressure } \\
\text { - } \quad \text { Benefits }\end{array}$ & (Shen et al., 2016) & 1 & 3.125 \\
\hline $\begin{array}{ll}\text { - } & \text { External } \\
\text { - } & \text { Property-level } \\
\text { - } & \text { Corporate-level } \\
\text { - } & \text { Project-level } \\
\text { - } & \text { Individual-level }\end{array}$ & (Darko, Zhang, et al., 2017) & 1 & 3.125 \\
\hline $\begin{array}{c}\text { Without } \\
\text { categorization }\end{array}$ & $\begin{array}{l}\text { (Chan et al., 2009), (M. Azizi \& Sakina, 2010), (Bond, 2010), } \\
\text { (Azis et al., 2013), (Lee et al., 2013), (Dahiru et al., 2014), } \\
\text { (Windapo, 2014), (Aste et al., 2016), (MacNaughton et al., 2016), } \\
\text { (Shazmin et al., 2016), (Olanipekun et al., 2017), (Azar \& Al } \\
\text { Ansari, 2017), (Yang et al., 2017), (Darko, Chan, et al., 2017) }\end{array}$ & 15 & 46.875 \\
\hline & Total & 32 & 100 \\
\hline
\end{tabular}

\subsubsection{Environmental Motivators}

Environmental motivators include; environmental protection, climate change, recycling and waste minimization. Tarja Hakkinen and Kaisa Belloni (2011) stated that according to the draft of ISO 21929 (2010a), climate change, deterioration of the ecosystem, and depletion of resources are considered as the main environmental reasons to motivate building stakeholders for the adoption of green building concept in their projects (Häkkinen \& Belloni, 2011).

Handan Gundogan (2012), pointed out in her study that, in Turkey 'Reducing negative impacts of buildings on environment' was the primary motivation for the implementation of green buildings, followed by 'Decreased use of natural resources', 'Control of the climate change', and 'Increased water and air quality' respectively (Gündoğan, 2012).

McGraw-Hill Construction, in its report 'World Green Building Trends: Business Benefits Driving New and Retrofit Market Opportunities in Over 60 Countries' (2013), showed that the 'Lower greenhouse gas emission' is considered the second most important environmental factor for European and Australian respondents, while, the 'Natural resource conservation' is considered as the second most important environmental reason in South Africa and Singapore (McGraw-Hill, 2013).

Waidyasekara and Fernando listed in their study; 'Benefits of Adopting Green Concept for Construction of Buildings in Sri Lanka', the top five environmental beneficial factors as; 'Lower potable water use', 'Better air quality inside the facility', 'Reduced energy use', 'Lower fossil fuel use', and 'Protection of ecological resources' respectively (Waidyasekara \& Fernando, 2013).

Naim H. Rustom (2014), believes that 'Increased material efficiency by reducing the material demand of non-renewable goods', 'Reduced material intensity via substitution technologies', 
'Enhanced material recyclability', 'Reduced and controlled use and dispersion of toxic materials', 'Reduced energy required for transforming goods and supplying services', 'Supporting the instruments of international conventions and agreements', 'Maximizing the sustainable use of biological and renewable resources', and 'Considering the impact of planned projects on air, soil, water, flora, and fauna' are the major environmental motivators for adopting green buildings.

Dodge Data and Analytics (2016), reported that 'Reducing energy consumption' continues to be the top environmental reason for building green by $66 \%$ of all respondents, followed by 'Protecting natural resources' which was ranked second globally, with 37\%, and 'Reducing water consumption' was third, with $31 \%$.

\subsubsection{Economic Motivators}

According to Tarja Hakkinen and Kaisa Belloni (2011), promoting the adoption of sustainable building concepts rely on economic factors such as: 'Beneficial operational costs of sustainable buildings', 'Improved well-being and productivity of occupants and users of buildings', and 'Long-term benefits for the national economy'.

Handan Gundogan in 2012, identified 'Lower annual energy cost', 'Lower annual water cost', and 'Increased profitability of company with improved productivity' as the main economic motivators for green building development and construction (Gündoğan, 2012).

A survey that was conducted in 2012 by McGraw-Hill Construction, points out that 'Client demand', 'Market demand' and 'Lower operating cost' constitute the major economic motivators for the implementation of green buildings (McGraw-Hill, 2013).

Based on the study conducted in Sri Lanka in 2013 by Waidyasekara and Fernando, most of the respondents believe that 'Lower energy cost', is the most effective economic motivator in adopting green buildings in Sri Lanka. It was identified that 'Lower annual electricity cost', 'Reduced annual water and wastewater cost', 'Lower annual fuel cost', and 'Lower cost for waste disposal' are the next top four economic motivators according to the respondents. It is obvious that most of the economic motivators are based on long term benefits, where they are achievable within two years of constructing the building (Waidyasekara \& Fernando, 2013).

Naim H. Rustom (2014), points out that 'Considering life-cycle costs', 'Internalizing external costs', 'Considering alternative financing mechanisms', 'Developing appropriate economic instruments to promote sustainable consumption', and 'Considering the economic impact on local structures' were the top five economic factors for the adoption of green design in building construction.

Usman and Gidado (2015), observed in their study 'An Assessment of the Factors Affecting Green Building Technology (GBT) Adoption', that the economic and financial benefits of green buildings include: 'Higher rents', 'Higher sales prices', 'Lower cost of occupancy', 'Greater tenant demand', 'Human capital savings', and 'Building value insurance'.

The results of a global survey conducted at 69 countries by Dodge Data and Analytics in 2016, showed that the 'client demand' which was consistently an important motivator for the 


\section{Macrothink}

previous two studies conducted in 2008 and 2012, takes a significant jump in 2015 as one of the top motivators for green building implementations for the future, and are followed by 'Market demands', and 'Lower operating cost' respectively (Dodge, 2016).

\subsubsection{Social Motivators}

The motivators; 'Improved quality of life', 'Well-being of occupants', and 'Better occupant health', are considered as the most important social factors for the adoption of green buildings, as stated by Gündoğan (2012), McGraw-Hill (2013), Waidyasekara and Fernando (2013), and Dodge Data and Analytics (2016). On the other hand, Hakkinen and Belloni (2011), and Usman and Gidado (2015) identified 'Health', 'Satisfaction', 'Equity', and 'Cultural value' as the majority of social motivators for the implementation of green buildings.

Moreover, Rustom (2014), observed that 'Enhancing a participatory approach by involving stakeholders', 'Promoting public participation', 'Promoting the development of appropriate institutional frameworks', 'Considering the influence on the existing social framework', and 'Assessing the impact on health and the quality of life' are the main important social motivators to implement the concept of green buildings.

\subsection{Efficiency of Green Building Motivators}

The efficiency of green building motivators varies from country (or region) to another, depending on the environmental, economic, and social conditions. Through a global survey conducted by Dodge Data and Analytics in 2016, it was found that; 'Client demands' ranked first in the list of top five motivators to increase levels of green buildings in UK and US, while it ranked the last in India and Colombia. On the other hand, it was found that 'Environmental regulations' has topped the list in UK, Singapore, and Australia, while tailed the list in Poland, Germany, and Saudi Arabia (Dodge, 2016). More details are shown in Figure 2. 


\section{Macrothink

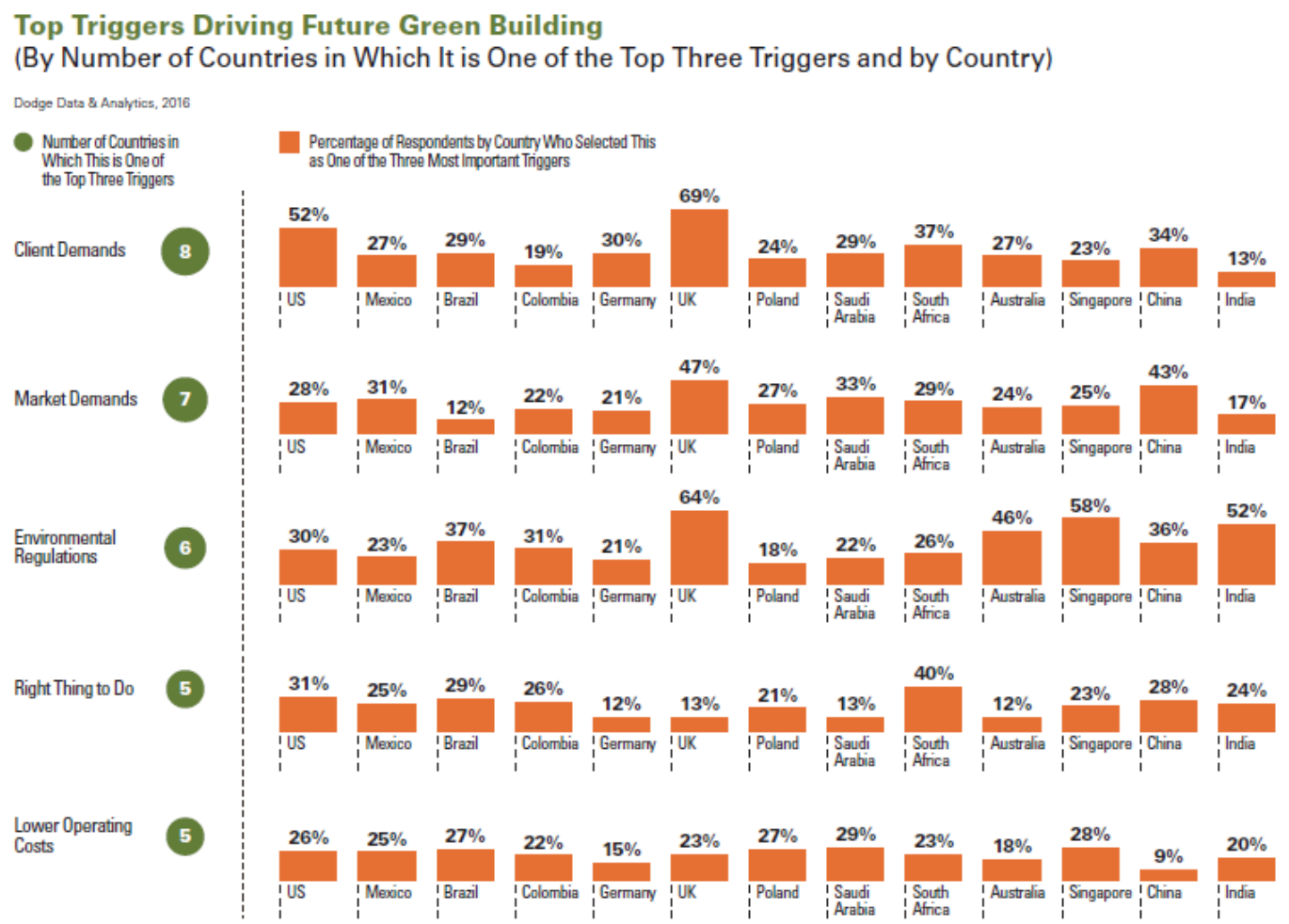

Figure 2. Top triggers driving future green building. (Dodge, 2016)

As a result of a survey conducted in Malaysia, among a number of stakeholders, the majority of respondents stated that legislations and policies have a higher influence than other motivators (Khoshnava, Rostami, Ismail, \& Lamit, 2014). Unlike the result obtained from other countries, the reason 'Satisfaction from doing the right thing' is a key social motivator driving the implementation of green buildings in South Africa (McGraw-Hill, 2013).

As to the situation in Turkey, based on Gundogan's study conducted in 2012, 'Lower annual water cost', 'Lower annual energy cost', and 'Increased profitability of company with improved productivity' were the top three important motivators for green building development, while, the 'Government support' listed at the end of the list of potential motivators (Gündoğan, 2012).

Abidin, and Powmya (2014) discusses the drivers to motivate development specialists to take an interest in executing a green concept into their construction projects and investigate the impression of these experts on the future standpoint of the green approach in Oman. Through surveys, the study found that 'A good way to protect the environment', 'Company cares for the society and the environment', and 'A safe way to avoid infringement of laws and regulations', were identified as the top effective motivators of green building adoption in Oman.

By comparing the results of this study given in Table 1 and Table 2, with the results of a global survey conducted by Dodge Data and Analytics in 2016, among 69 countries regarding to the top triggers driving future green buildings presented in Figure 2, it was found that there is a correlation between these results. It was observed from Table 1 that the "Client Demand" 
factor was cited as one of the significant motivators for green buildings in each of the studies conducted in Australia, Saudi Arabia and China, which are among the countries referred in the Dodge Data and Analytics survey, that considered this factor as one of the top three motivators. On the other hand, 'Environmental Regulations' factor was cited in the studies conducted in Singapore, and China as the top possible motivators for green buildings, while, it was ranked as the highly influenced in Singapore, in the Dodge Data and Analytics survey. Regarding the 'Right Thing to Do' factor, it was cited as one of the top possible motivators for green buildings in studies conducted in South Africa, and Singapore, which was considered as having the greatest influence in the Dodge Data and Analytics survey.

\subsection{Strategies for Green Building Motivators}

Many studies have suggested strategies and policies to enhance the efficiency of motivators for the implementation of green buildings. The significant ones are summed up below:

\subsubsection{Management Support}

It is notable that the government has the most important role to motivate the stakeholders, in order to adopt and implement the green building concept. Some of the policies that the government can take to support green buildings are; 'Make policy to promote green building assessment'. 'Legislate against energy use', Financial incentive mechanisms', 'Convert government building projects into green buildings', and 'Local government tax concessions for green buildings' (Abidin \& Powmya, 2014; Bond, 2010; Deutsche, 2016; Gündoğan, 2012; Hankinson \& Breytenbach, 2012; Mosly, 2015; Shi, 2009; Yen et al., 2016).

\subsubsection{Education and Development}

The extent to which stakeholders are aware of green building incentives is positively reflected in the widespread adoption and implementation of the green building concept. Several previous studies have indicated the importance of this strategy, which include; 'Development of designers' competence and team working', 'Created education programs', 'Improving sustainable design knowledge', 'Improving knowledge and scope of products and materials', 'Educating clients and utilizing rating tools', 'Improving knowledge of economic performance', 'Encouraging green building research', 'Enhancing research collaborations on sustainability issues among academic staffs, students and outsiders', and 'Training people in the building sector through workshops and seminars' (Abidin \& Powmya, 2014; Alrashed \& Asif, 2014; AlSanad, 2015; Darko, Chan, et al., 2017; Gohardani, 2014; Gündoğan, 2012; Häkkinen \& Belloni, 2011; Hankinson, 2012; Hankinson \& Breytenbach, 2012; Mosly, 2015; Wimala, Akmalah, Irawati, \& Sururi, 2016).

\subsubsection{Contribution of Private Sector}

Although the government has the greatest role to motivate the stakeholders to adopt and implement green buildings, the private sector also has an important role (Olubunmi et al., 2016). For example, the private sector may offer electricity and water subsidies for the payments of water and energy utilities (Mosly, 2015; Song \& Peña-Mora, 2012). Private sector can also enlighten the public regarding the benefits of green buildings and increase the 
publicity and awareness through the media (Dahiru et al., 2014; Darko, Chan, et al., 2017; Olubunmi et al., 2016).

\subsubsection{Role of Green Building Bodies}

Green building bodies such as 'Green Building Councils' have a vital role in encouraging stakeholders in the built environment in adopting green building practices (D. O. Nduka \& Sotunbo, 2014). It is very difficult and almost impossible for stakeholders to succeed in applying green buildings without any support or guidance (Aktas \& Ozorhon, 2015). Establishment of an official green building body is considered as the most important strategy for spreading the application of green buildings (Alrashed \& Asif, 2014; AlSanad, 2015; Elfiky, 2011; Mosly, 2015; D. O. Nduka \& Sotunbo, 2014; Shi, 2009; Yen et al., 2016; Y. Zhang, Wang, Hu, \& Wang, 2017; Z. Zhang, Hu, \& Shen, 2017). Many countries established a local green building rating system to encourage and motivate stakeholders in the construction industry to adopt the green building concept in their designs. These rating systems were created to be one of the most important motivators for green building development (Darko, Zhang, et al., 2017).

\section{Conclusion}

This paper presents a systematic review of the studies on green building motivators. The aim of this study was to identify and categorize the important motivators for the adoption of green buildings which have been mentioned in the literature, as well as to analyze the efficiency and strategies regarding this issue. 26 green building motivators were identified by reviewing 32 relevant studies conducted in different countries from 2008 to 2017.

It was seen that, studies have classified the green building motivators in different ways. Some classified them on the basis of internal and external factors, some used a financial and non-financial basis, and others classified them according to their environmental, economic, and social aspects. On the other hand, most of them only identified these motivators without any classification. This study has classified the green building motivators which were derived from an in-depth literature review, under three main categories, as: environmental, economic, and social motivators. These motivators are summarized in Table 4, under the mentioned classification system.

With regard to efficiency, it was found that all green building motivators, whether environmental, economic or social are important for promoting green buildings and a certain priority among them was not observed. Overall, the efficiency of green building motivators varies from country (or region) to another, depending on the environmental, economic, and social conditions of the location of study. While the economic motivators played the most important role in both US and Turkey, the environmental motivators were the most important ones in the UK, Australia, and Singapore. Moreover, social motivators were considered the most important in both South Africa and Oman.

In terms of strategies, some studies have suggested strategies and policies to enhance the efficiency of motivators for the implementation of green buildings. These strategies enable stakeholders to benefit from green buildings and therefore encourage them to adopt green 
design. These strategies can be summarized as: 'Government Support', 'Education and Development', 'Contribution of Private Sector', and 'Role of green building bodies'. Overall, it can be stated that the government has the greatest role to motivate stakeholders to adopt and implement the green building concept.

Table 5. Green building motivators derived from literature review, (produced by the author)

\begin{tabular}{|c|c|c|}
\hline No: & Categorized & Motivators \\
\hline 1 & \multirow{6}{*}{ Environmental } & Protection of the environment and ecosystem \\
\hline 2 & & Control of climate change. \\
\hline 3 & & Compatibility with environmental regulations \\
\hline 4 & & Increasing indoor air quality \\
\hline 5 & & Recycling and waste reduction \\
\hline 6 & & Improve reusable and recycle building elements \\
\hline 7 & \multirow{13}{*}{ Economic } & Increasing building quality and value \\
\hline 8 & & Providing lower operation, maintenance, and repair cost \\
\hline 9 & & Providing lower building life-cycle cost \\
\hline 10 & & Providing a good opportunity for investment returns \\
\hline 11 & & Increasing occupant productivity \\
\hline 12 & & Increasing occupancy rate \\
\hline 13 & & Increasing rental and sale value \\
\hline 14 & & Providing lower annual energy cost \\
\hline 15 & & Providing lower water and wastewater cost \\
\hline 16 & & Giving a good reputation for marketers \\
\hline 17 & & Availability of more financing channels \\
\hline 18 & & Increase in demand of clients/tenants \\
\hline 19 & & Product and material innovation and/or certification \\
\hline 20 & \multirow{7}{*}{ Social } & Providing improved comfort, health, and well-being of occupants \\
\hline 21 & & Improving the quality of life for individuals \\
\hline 22 & & Satisfaction from doing the right thing \\
\hline 23 & & Government regulations and policies \\
\hline 24 & & Moral imperative or social conscience \\
\hline 25 & & Creating of better future opportunities \\
\hline 26 & & Self-identity \\
\hline
\end{tabular}

What distinguishes this research from similar ones in literature which are mostly specific to a country or region is that, the source of the data is diverse and up-to-date, covering studies on different countries of the world, conducted within the last ten years. From this extensive and systematic literature review, a total of 26 motivators for the implementation of green buildings were derived from environmentally, economically, and socially differing communities, and also were classified based on these three aspects, as mentioned above.

The motivators that have been mentioned in this paper have general applicability for all stakeholders related to the green building industry. This paper is expected to provide valuable 
information for decision-makers in the construction industry, regarding what motivates people to help further promote green buildings. The findings of the study may also be useful for researchers who would undertake further analyses on a similar topic.

\section{References}

Abidin, N. Z., \& Powmya, A. (2014). Perceptions on motivating factors and future prospects of green construction in Oman. Journal of Sustainable Development, 7(5), 231.

https://doi.org/10.5539/jsd.v7n5p231

Aktas, B., \& Ozorhon, B. (2015). Green building certification process of existing buildings in developing countries: Cases from Turkey. Journal of Management in Engineering, 31(6), 05015002. https://doi.org/10.1061/(ASCE)ME.1943-5479.0000358

Alrashed, F., \& Asif, M. (2014). Saudi building industry's views on sustainability in buildings: Questionnaire survey. Energy Procedia, 62, 382-390.

https://doi.org/10.1016/j.egypro.2014.12.400

AlSanad, S. (2015). Awareness, drivers, actions, and barriers of sustainable construction in Kuwait. Procedia Engineering, 118, 969-983. https://doi.org/10.1016/j.proeng.2015.08.538

Aste, N., Caputo, P., Buzzetti, M., \& Fattore, M. (2016). Energy efficiency in buildings: What drives the investments? The case of Lombardy Region. Sustainable Cities and Society, 20, 27-37. https://doi.org/10.1016/j.scs.2015.09.003

Azar, E., \& Al Ansari, H. (2017). Framework to investigate energy conservation motivation and actions of building occupants: The case of a green campus in Abu Dhabi, UAE. Applied Energy, 190, 563-573. https://doi.org/10.1016/j.apenergy.2016.12.128

Azis, S. S. A., Sipan, I., \& Sapri, M. (2013). The potential of implementing property tax incentives on green building in Malaysia. American Journal of Economics, 3(2), 63-67.

Azizi, M., \& Sakina, N. (2010). Risks associated in implementation of green buildings. Beyond Today'S Infrastruct.

Azizi, N., Fassman, E., \& Wilkinson, S. (2010). Risks Associated in Implementation of Green Buildings. Beyond Today's Infrstructure.

Bond, S. (2010). Best of the best in green design: drivers and barriers to sustainable development in Australia. Paper presented at the Proceedings of the 16th annual conference of the Pacific Rim Real Estate Society, Sydney, Australia.

Butera, F. M. (2010). Climatic change and the built environment. Advances in Building Energy Research, 4(1), 45-75. https://doi.org/10.3763/aber.2009.0403

Chan, E. H., Qian, Q. K., \& Lam, P. T. (2009). The market for green building in developed Asian cities-the perspectives of building designers. Energy Policy, 37(8), 3061-3070. https://doi.org/10.1016/j.enpol.2009.03.057

Construction, T. (2008). Green building market barometer. In: New York: Turner 
Construction.

Dahiru, D., Dania, A., \& Adejoh, A. (2014). An Investigation into the Prospects of Green Building Practice in Nigeria. Journal of Sustainable Development, 7(6), 158.

https://doi.org/10.5539/jsd.v7n6p158

Darko, A., Chan, A. P. C., Ameyaw, E. E., He, B.-J., \& Olanipekun, A. O. (2017). Examining issues influencing green building technologies adoption: The United States green building experts' perspectives. Energy and Buildings. https://doi.org/10.1016/j.enbuild.2017.03.060

Darko, A., Zhang, C., \& Chan, A. P. (2017). Drivers for green building: A review of empirical studies. Habitat International, 60, 34-49. https://doi.org/10.1016/j.habitatint.2016.12.007

Deutsche Gesellschaft fur Internationale Zusammenarbeit (GIZ) GmbH (2016). Promoting sustainable and inclusive growth in emerging economies: Green Buildings. Retrieved from https://economic-policy-forum.org/wp-content/uploads/2016/02/Sustainable-and-Inclusive-G rowth-Green-Buildings.pdf

Dixon, T., McNamara, P., \& Newell, G. (2008). The strategic significance of environmental sustainability by Australian-listed property trusts. Journal of Property Investment \& Finance, 26(6), 522-540. https://doi.org/10.1108/14635780810908370

Diyana, A. N., \& Abidin, N. Z. (2013). Motivation and expectation of developers on green construction: a conceptual view. Paper presented at the Proceedings of World Academy of Science, Engineering and Technology.

Dodge Data and Analytics (2016). World Green Building Trends 2016: Developing Markets Accelerate Global Green Growth. Retrieved from

http://analyticsstore.construction.com/2016WorldGreen-9408.html

Elfiky, U. (2011). Towards a green building law in Egypt: Opportunities and challenges. Energy Procedia, 6, 277-283. https://doi.org/10.1016/j.egypro.2011.05.031

Falkenbach, H., Lindholm, A.-L., \& Schleich, H. (2010). Review articles: environmental sustainability: drivers for the real estate investor. Journal of Real Estate Literature, 18(2), 201-223.

Gohardani, N. (2014). An Approach Towards Sustainable Building. KTH Royal Institute of Technology,

Gündoğan, H. (2012). Motivators and Barriers for Green Building Construction Market in Turkey. MIDDLE EAST TECHNICAL UNIVERSITY,

Häkkinen, T., \& Belloni, K. (2011). Barriers and drivers for sustainable building. Building Research \& Information, 39(3), 239-255. https://doi.org/10.1080/09613218.2011.561948

Hankinson, M. (2012). Factors that impact on the implementation of sustainable interior design in KwaZulu-Natal. (Master), University of Johannesburg,

Hankinson, M., \& Breytenbach, A. (2012). Barriers that impact on the implementation of 
sustainable design. Cumulus Helsinki, 1-11.

Kerr, P. (2008). High Performance Buildings: The Process of Delivery for Universities and Colleges. HW University, Heriot, Scotland, 30.

Khoshnava, S. M., Rostami, R., Ismail, M., \& Lamit, H. (2014). Obstacles and drivers in steering IBS towards green and sustainability. Research Journal of Applied Sciences, Engineering and Technology, 8(14), 1639-1647. https://doi.org/10.19026/rjaset.8.1145

Lam, P. T., Chan, E. H., Poon, C., Chau, C., \& Chun, K. (2010). Factors affecting the implementation of green specifications in construction. Journal of environmental management, 91(3), 654-661. https://doi.org/10.1016/j.jenvman.2009.09.029

Lee, S., Lee, B., Kim, J., \& Kim, J. (2013). A financing model to solve financial barriers for implementing green building projects. The Scientific World Journal, 2013.

https://doi.org/10.1155/2013/240394

MacNaughton, P., Spengler, J., Vallarino, J., Santanam, S., Satish, U., \& Allen, J. (2016). Environmental perceptions and health before and after relocation to a green building. Building and Environment, 104, 138-144. https://doi.org/10.1016/j.buildenv.2016.05.011

McGraw-Hill. (2013). World Green Building Trends: Business Benefits Driving New and Retrofit Market Opportunities in Over 60 Countries. Retrieved from

http://analyticsstore.construction.com/world-green-building-trends-smartmarket-report-2013. html

Mosly, I. (2015). Barriers to the Diffusion and Adoption of Green Buildings in Saudi Arabia. Journal of Management and Sustainability, 5(4), 104. https://doi.org/10.5539/jms.v5n4p104

Nduka, D. O., \& Sotunbo, A. S. (2014). Stakeholders Perception on the Awareness of Green Building Rating Systems and Accruable Benefit in Construction Projects in Negeria. Journal of sustainable Development in Africa, 16(7).

Nduka, D., \& Ogunsanmi, O. (2015). Stakeholders perception of factors determining the adoptability of green building practices in construction projects in Nigeria. Journal of Environment and Earth Science, 5(2), 188-196.

Ng, E. (2013). Impact of Green Buildings on the Value of Property. Built Environment: Environmental Design and Engineering MSc Thesis. University College London, United Kingdom.

Odebiyi Sunday, O., Subramanian, S., \& Braimoh, A. K. (2010). Green architecture: merits for Africa (Nigerian case study). J Altern Perspect Soc Sci, 2(2), 746-767.

Olanipekun, A. O. (2016). The Levels of Building Stakeholders' Motivation for Adopting Green Buildings. 21st Century Human Habitat: Issues, Sustainability and Development, 8-19.

Olanipekun, A. O., Xia, B. P., \& Nguyen, H.-T. (2017). Motivation and Owner Commitment for Improving the Delivery Performance of Green Building Projects: A Research Framework. 
Olubunmi, O. A., Xia, P. B., \& Skitmore, M. (2016). Green building incentives: A review. Renewable and Sustainable Energy Reviews, 59, 1611-1621.

https://doi.org/10.1016/j.rser.2016.01.028

Qi, G., Shen, L. Y., Zeng, S., \& Jorge, O. J. (2010). The drivers for contractors' green innovation: an industry perspective. Journal of Cleaner Production, 18(14), 1358-1365. https://doi.org/10.1016/j.jclepro.2010.04.017

Rustom, N. H. (2014). Promoting Green Buildings Practices in Palestine, 2014.

Shazmin, S., Sipan, I., \& Sapri, M. (2016). Property tax assessment incentives for green building: A review. Renewable and Sustainable Energy Reviews, 60, 536-548.

https://doi.org/10.1016/j.rser.2016.01.081

Shen, L., Zhang, Z., \& Zhang, X. (2016). Key factors affecting green procurement in real estate development: a China study. Journal of Cleaner Production.

Shi, Q. (2009). Strategies of implementing a green building assessment system in mainland China. Journal of Sustainable Development, 1(2), 13. https://doi.org/10.5539/jsd.v1n2p13

Song, X., \& Peña-Mora, F. (2012). Introducing the concept of emissions liability insurance in managing greenhouse gas (GHG) emissions and promoting sustainability in construction projects. Paper presented at the Construction Research Congress 2012: Construction Challenges in a Flat World.

Suzer, O. (2015). A comparative review of environmental concern prioritization: LEED vs other major certification systems. Journal of environmental management, 154, 266-283. https://doi.org/10.1016/j.jenvman.2015.02.029

USGBC. (2012). Definition of Green Building. Green Buildings Retrieved from http://www.epa.gov/greenbuilding/pubs/about.htm

Usman, N., \& Gidado, U. M. (2015). An Assessment of the Factors Affecting Green Building Technology (GBT) Adoption. Jeddah Saudi Arabia, 13(01).

Varma, K., Chaurasia, M., Shukla, P., \& Ahmed, T. (2014). Green Building Architecture: A Literature Review on Designing Techniques. International Journal of Scientific and Research Publications, 583.

Waidyasekara, K., \& Fernando, W. (2013). Benefits of adopting green concept for construction of buildings in Sri Lanka.

Weeks, J. A. (2010). Understanding the issues of project cost and time in sustainable construction from a general contractor's perspective: case study. Georgia Institute of Technology,

Wimala, M., Akmalah, E., Irawati, I., \& Sururi, M. R. (2016). Overcoming the Obstacles to Green Campus Implementation in Indonesia. World Academy of Science, Engineering and Technology, International Journal of Civil, Environmental, Structural, Construction and Architectural Engineering, 10(10), 1316-1321. 


\section{Macrothink}

Environmental Management and Sustainable Development

ISSN 2164-7682 2018, Vol. 7, No. 2

Windapo, A. O. (2014). Examination of green building drivers in the South African construction industry: economics versus ecology. Sustainability, 6(9), 6088-6106.

https://doi.org/10.3390/su6096088

Yang, Y. X. O., Chew, B. C., Loo, H. S., \& Tan, L. H. (2017). Green commercial building insurance in Malaysia. Paper presented at the AIP Conference Proceedings. https://doi.org/10.1063/1.4976935

Yen, T. K., Mohammad, I. S., Baba, M., Jalil, R. A., Zainol, N. N., Woon, N. B., \& Abdullah, S. (2016). Factors Hindering Green Building Performance: A Review. Sains Humanika, 8(4-3). https://doi.org/10.11113/sh.v8n4-3.1083

Yudelson, J. (2013). Green building A to Z: understanding the language of green building: New Society Publishers.

Zhang, Y., Wang, J., Hu, F., \& Wang, Y. (2017). Comparison of evaluation standards for green building in China, Britain, United States. Renewable and Sustainable Energy Reviews, 68, 262-271. https://doi.org/10.1016/j.rser.2016.09.139

Zhang, Z., Hu, J., \& Shen, L. (2017). Green Procurement Management in Building Industry: An Alternative Environmental Strategy. Paper presented at the Proceedings of the 20th International Symposium on Advancement of Construction Management and Real Estate. https://doi.org/10.1007/978-981-10-0855-9_107

\section{Copyright Disclaimer}

Copyright for this article is retained by the author(s), with first publication rights granted to the journal.

This is an open-access article distributed under the terms and conditions of the Creative Commons Attribution license (http://creativecommons.org/licenses/by/3.0/). 